\title{
Effect of inoculation of Bacillus strains on flowering of carnation (Dianthus caryophyllus)
}

\section{Efecto de la inoculación de cepas de Bacillus sobre la floración de clavel (Dianthus caryophyllus)}

GARCÍA-BARAJAS, Margarita-Guadalupe $\dagger^{\prime}$, HERNÁNDEZ-MORALES, Alejandro", CHÁVAROORTÍZ, María del Socorro' and PACHECO-AGUILAR, Juan-Ramiro*'

Universidad Autónoma de Querétaro, Faculty of Chemistry, Cerro de las campanas s / n, col. Las Campanas, C.P. 76040. Santiago de Querétaro Qro. Mexico.

'Universidad Autónoma de San Luis Potosí. Faculty of Professional Studies Huasteca Zone, Romualdo del Campo 501, Fraccionamiento Rafael Curiel, CP 79060, Ciudad Valles San Luis Potosí, Mexico.

ID $1^{\text {st }}$ Author: Margarita Guadalupe, García-Barajas / ORC ID: 0000-0002-0656-3918, CVU CONACYT ID: 926190

ID $1^{\text {st }}$ Co-author: Alejandro, Hernández-Morales / ORC ID: 0000-0002-0412-4946, Researcher ID Thomson: P-84412014, CVU CONACYT ID: 101590

ID $2^{\text {nd }}$ Co-author: María del Socorro, Chávaro-Ortíz / ORC ID: 0000-0013-7516-1675, CVU CONACYT ID: 289699

ID $3^{\text {rd }}$ Co-author: Juan-Ramiro, Pacheco-Aguilar / ORC ID: 0000-0001-8365-4488, CVU CONACYT ID: 87499

DOI: $10.35429 / J N A S .2020 .21 .7 .21 .25$

Received July 20, 2020; Accepted December 30, 2020

\begin{abstract}
The carnation flower (Dianthus caryophyllus) is one of the most accepted and distributed worldwide, for its production, fertilization and the application of phytohormones have been optmized, thereby seeking to improve flower quality. However, little has been tested on the effect of the application of plant growth promoting bacteria. In the present work, carnation plants cv. Lilliput, were inoculated with $5 \times 10^{7}$ cells of Bacillus megaterium M6 and Bacillus subtilis P12, both individually and in interaction (M6 x P12), registering agronomic parameters related to flowering. The results showed that none of the inoculations had an effect on the percentage of flowering plants, neither on the height nor the diameter of the flower, only P12 increased flower number per plant by $38 \%$, compared to the control without inoculation. Being the period between 96 and 127 days after transplantation (dat), where tha highest number of total flowers was recorded (70) with respect to the other treatments (M6:36, M6 x P12: 24 and control: 32). In conclusion, Bacillus subtilis $\mathrm{P} 12$ has a promoter activity to improve the flowering of carnation plants.
\end{abstract}

Biofertilizers, Phytohormones, Phosphate solubilization

\begin{abstract}
Resumen
La flor de clavel (Dianthus caryophyllus) es una de las más aceptadas y distribuidas mundialmente, para su producción se ha optimizado la fertilización y la aplicación de fitohormonas, buscando con ello mejorar la calidad de la flor, sin embargo, poco se ha ensayado sobre el efecto de la aplicación de bacterias promotoras del crecimiento vegetal. En el presente trabajo, plantas de clavel cv. Lilliput, fueron inoculadas con $5 \times 10^{7}$ células de Bacillus megaterium M6 y Bacillus subtilis P12, tanto de forma individual como en interacción (M6 x P12), registrando durante tres meses, variables agronómicas relacionadas con la floración. Los resultados mostraron que ninguna inoculación tuvo efecto sobre el porcentaje de plantas con flor, ni en la altura ni el diámetro de la flor, solo P12 incrementó el número de flores por planta en un $38 \%$ con respecto al testigo sin inocular. Siendo el periodo comprendido entre los 96 y 127 días después del trasplante $(\mathrm{ddt})$, donde se registró el mayor número de flores totales (70) con respecto a los demás tratamientos (M6:36, M6 x P12: 24 y testigo: 32). En conclusión, Bacillus subtilis P12 posee actividad promotora para mejorar la floración de plantas de clavel.
\end{abstract}

Biofertilizantes, Fitohormonas, Solubilización de fosfatos

Citation: GARCÍA-BARAJAS, Margarita-Guadalupe, HERNÁNDEZ-MORALES, Alejandro, CHÁVARO-ORTÍZ, María del Socorro and PACHECO-AGUILAR, Juan-Ramiro. Effect of inoculation of Bacillus strains on flowering of carnation (Dianthus caryophyllus). Journal of Natural and Agricultural Sciences. 2020. 7-21:21-25.

\footnotetext{
* Author Correspondence (Email: juanramiro29@yahoo.com.mx)

$\dagger$ Researcher contributing as first author.
} 


\section{Introduction}

The carnation flower is among the most commercialized worldwide along with the rose and the chrysanthemum. For its production, it is essential to consider cultural tasks, growth substrates, nutrition through fertilization (Devi, 1999) and the use of phytohormones that favor greater flowering (Zheng et al., 2020).

In the establishment of the crop, substrates such as rice husk, coconut fiber and perlite have been shown to be effective for rooting cuttings (Baracaldo et al., 2010), while optimizing the application of chemical fertilizers that provide nitrogen and phosphorus has been decisive for the vegetative development and flowering of the crop (Devi, 1999), the use of compost from plant and animal residues has also been tested with promising results (Parmar et al., 2020; Yasmeen et al., 2012).

Among the phytohormones that have been shown to improve the rooting of cuttings are naphthalacetic acid (NAA) and indole butyric acid (IBA) (Zheng et al., 2020). While indoleacetic acid (IAA) and gibberellic acid have been used with favorable effects, increasing not only the vegetative development such as the height of the plant, the number of leaves and lateral shoots, but also reducing the flower initiation time, increased the number of flowers per plant and the diameter of the flower (Kumar et al., 2012).

Among the new agronomic technologies for organic production is the use of biofertilizers, which are microorganisms that, when inoculated to plants, promote vegetative development, increasing production and the quality of crops, this through various biochemical mechanisms such as such as the production of phytohormones, the biological fixation of nitrogen, the reduction of environmental stress and the improvement of the acquisition of nutrients from the soil such as phosphorus, iron and potassium (Vessey, 2003). These microorganisms, also called plant growth promoters, have been widely used in cereal, vegetable and forest crops, but little have been tested in floriculture (Arriaga et al., 2009).

In the present work the effect of the inoculation of Bacillus megaterium M6 and Bacillus subtilis $\mathrm{P} 12$ on the flowering of carnation plants cv. Lilliput.

\section{Methodology to be developed}

\section{Biological material}

Bacillus megaterium M6 and Bacillus subtilis P12 strains are isolated from agricultural soils, which are characterized as promoters of tomato and pepper plant growth (Luna et al., 2013), for their cultivation the nutritive broth medium was used. Regarding the plant material, carnation plants cv. Lilliput of 2.5-month-old from Villa Guerrero (state of Mexico) were transplanted into plastic pots $20 \mathrm{~cm}$ by $16 \mathrm{~cm}$ deep, which contained a mixture of peat moss and vermiculite 1: 1 (Gayosso et al., 2016). After a week, fertilization was started every third day, using the Peters Professional 10-30-20 Scotts nutrient solution (1 g / L). Trimming being performed 20 days after transplantation (dat).

\section{Bacterial inoculation}

To inoculate the plants with the plant growth promoting bacteria, the M6 and P12 strains were grown in $150 \mathrm{~mL}$ of nutrient broth at $30^{\circ} \mathrm{C}$ with constant shaking of $180 \mathrm{rpm}$ in an orbital for 18 hours. Afterwards, the cultures were centrifuged at $5000 \mathrm{rpm}$ for $10 \mathrm{~min}$ to recover the cell pellet, which was resuspended in $0.85 \% \mathrm{NaCl}$ saline solution and centrifuged again to eliminate remains of the culture medium. The pellet was finally resuspended in the minimum volume of saline solution to quantify the cell density using a Neubauer chamber and an optical microscope.

For the inoculation of the plants, dilutions were prepared at a concentration of $1 \times 10^{7}$ cells / $\mathrm{mL}$ (Arriaga et al., 2009), inoculating each plant with $5 \mathrm{~mL}$ at 20 days after transplantation (dat), then at 50 dat it was performed a second inoculation with the same number of cells. The test consisted of the following four treatments: 1) Inoculation with Bacillus megaterium M6, 2) Inoculation with Bacillus subtilis P12, 3) Mixture of both Bacillus M6 x P12 and 4) Control plants (B) without inoculation. The experimental unit consisted of 8 pots ( 1 plant per pot), with 6 repetitions for each treatment.
GARCÍA-BARAJAS, Margarita-Guadalupe, HERNÁNDEZMORALES, Alejandro, CHÁVARO-ORTÍZ, María del Socorro and PACHECO-AGUILAR, Juan-Ramiro. Effect of inoculation of Bacillus strains on flowering of carnation (Dianthus caryophyllus). Journal of Natural and Agricultural Sciences. 2020 


\section{Evaluation of flowering parameters}

Once flowering started, the following parameters were recorded daily for each plant. Number of flowers per plant: number of flowers that were presented in a pot throughout the experimental development, for this the opening dates of each flower were recorded, including the secondary flowers. Flowering plants: Number of plants from each treatment that had at least one flower during the trial. Flower diameter: It was measured from petal to petal, in completely open flowers, as shown in Figure 1 (Arriaga et al., 2009). Stem length: it was measured from the base of the substrate to the calyx of the flower (Baracaldo et al., 2010) (Fig. $1)$.

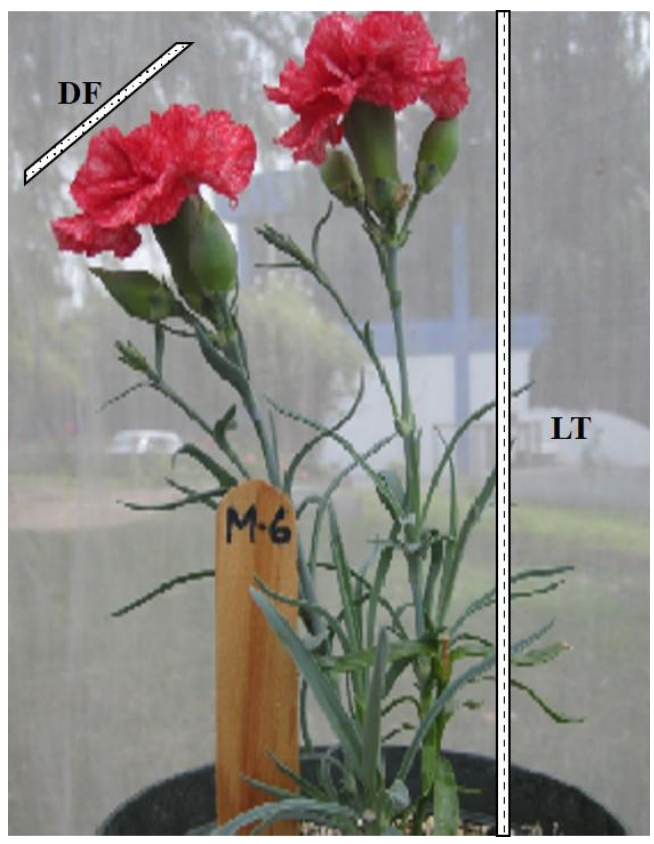

Figure 1 Flowering variables recorded in carnation plants cv. Lilliput. DF: Flower diameter, LT: Stem length

\section{Statistical analysis}

The data on the number of flowering plants were expressed as a percentage and transformed to angular degrees for analysis. All data were subjected to an analysis of variance (ANOVA) and Duncan's mean comparison test $(\mathrm{p}<0.05)$.

\section{Results}

\section{Effect of inoculation on flowering}

Flowering within the trial started in the control plants at 38 dat, followed by the plants inoculated with M6 (46 dat), then by P12 (49 dat), and finally by the M6 x P12 interaction (52 dat). Graphic 1 shows the flowering kinetics around the 127 dat that lasted in the test. We can see that the control plants had the lowest number of flowers per treatment (97 flowers), the M6 treatments and the M6 x P12 interaction, presented similar values in the number of total flowers, 134 and 120, respectively. Finally, the treatment that produced the highest number of flowers during the entire trial was P12 with 162. In the same graph we can see that it was in the second period between 66 and 99 dat, where the highest number of flowers was found for the treatments with M6, M6 x P12 and the control, and then, in the third period between 96 and 127 dat, flowering decreased in all treatments with respect to the previous period. This did not happen with the plants inoculated with P12, since flowering was kept constant during the second and third periods.

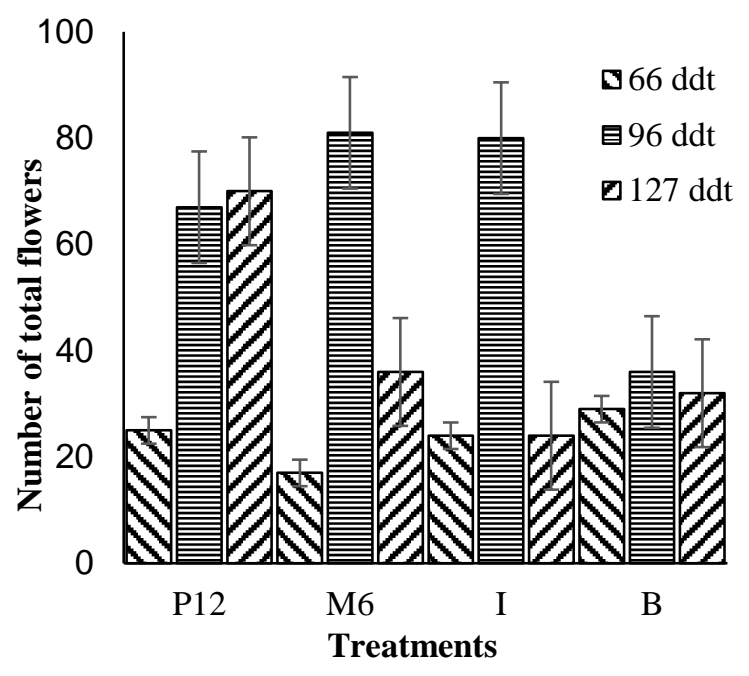

Graphic 1 Number of total flowers per treatment. M6: inoculation with Bacillus megaterium, P12: inoculation with Bacillus subtilis, I: M6 x P12 interaction, B: uninoculated control

Regarding the effect of inoculation on the flowering variables (Figure 2), we can see in Table 1, that only P12 had a positive effect on the number of flowers per plant, finding an increase of $38 \%$ compared to the control without inoculation. 


\begin{tabular}{|c|c|c|c|c|}
\hline Treatment & $\begin{array}{c}\% \text { Of } \\
\text { flowering } \\
\text { plants }\end{array}$ & $\begin{array}{c}\text { Flower } \\
\text { diameter } \\
(\mathrm{cm})\end{array}$ & $\begin{array}{l}\text { Stem } \\
\text { length } \\
(\mathrm{cm})\end{array}$ & $\begin{array}{l}\text { Number } \\
\text { of flowers } \\
\text { per plant }\end{array}$ \\
\hline M6 & $67 \% \mathrm{~A}$ & $4.8 \mathrm{~A}$ & $14.8 \mathrm{~A}$ & $3.94 \mathrm{AB}$ \\
\hline P12 & $75 \% \mathrm{~A}$ & $4.8 \mathrm{~A}$ & $14.0 \mathrm{~A}$ & $4.32 \mathrm{~A}$ \\
\hline M6 x P12 & $75 \% \mathrm{~A}$ & $4.7 \mathrm{~A}$ & $15.0 \mathrm{~A}$ & $3.30 \mathrm{~B}$ \\
\hline Control & $72 \% \mathrm{~A}$ & $4.8 \mathrm{~A}$ & $14.4 \mathrm{~A}$ & $3.13 \mathrm{~B}$ \\
\hline
\end{tabular}

Table 1 Effect of the inoculation of Bacillus megaterium M6 and Bacillus subtilis P12 strains on the agronomic variables of carnation flowering cv. Lilliput. Same letters in each column are not statistically different (Duncan, $0.05)$

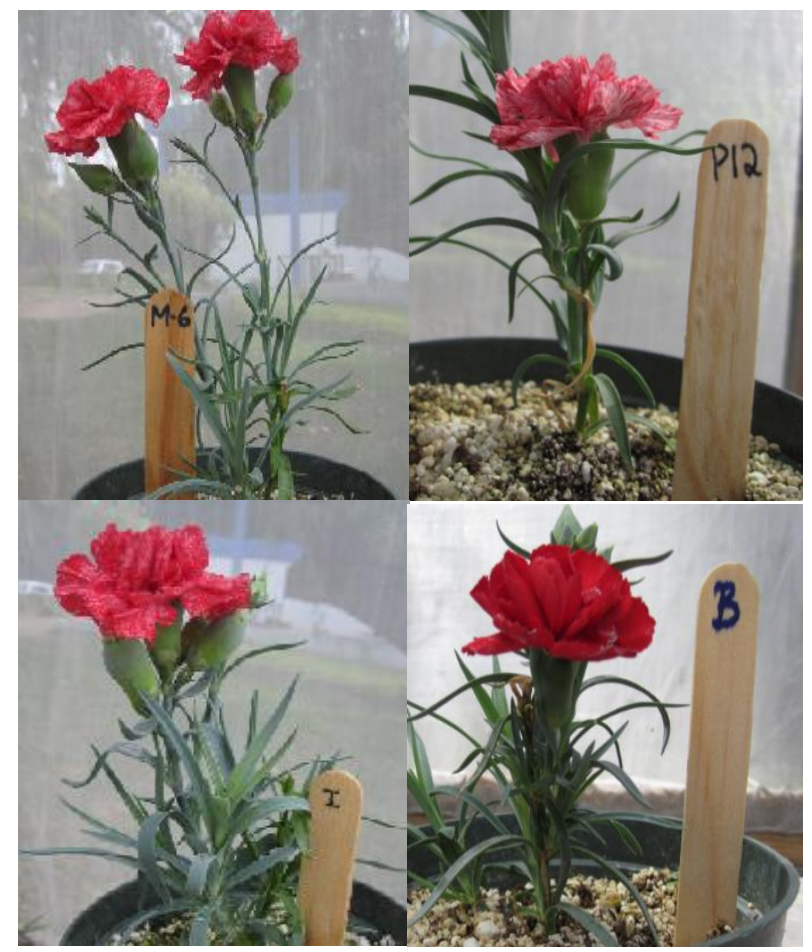

Figure 2 Carnation plants flowering. M6: inoculation with Bacillus megaterium, P12: inoculation with Bacillus subtilis, I: M6 x P12 interaction, B: uninoculated control.

The effect of Bacillus strains on flowering has been reported. Chavez et al. (2016) report that the inoculation of Mammillaria zeilmanniana cactus plants with Bacillus flexus QA24 increased the number of flowering plants by $31 \%$. This is probably due to the production of indoleacetic acid (IAA), and the ability to solubilize phosphates, biochemical properties exhibited by the P12 strain (Luna et al., 2013), and which may have intervened in the metabolic processes that led to greater flowering rate.

The application of exogenous IAA has important effects on carnation flowering, Kumar et al. (2012) report that the 100 ppm spray in $\mathrm{cv}$. Lilliput, increased the height of the plant by 1.84 $\mathrm{cm}$ and the number of shoot shoots by 1.32 units. In addition, I advance the start of flowering by four days and increase the number of flowers per plant by 3.01 units.
The amount of IAA used with these results (100 ppm), considerably exceeds that which could produce P12, which under laboratory conditions produced $6.67 \mathrm{ppm}$. Which could explain the low effect on the plants in the trial. Although these concentrations are minimal, they could have an effect on the number of flowers per plant.

Regarding plant nutrition through chemical fertilization, Devi, (1999) reports that the application of $20 \mathrm{~g}$ of phosphorus $/ \mathrm{m}^{2}$ (as simple superphosphate), increased the number of carnation flowers per plant (cv. Caberet) by one unit. Although Bacillus subtilis P12 presents phosphate solubilization (18.5 ppm) (Luna et al., 2013) under laboratory conditions, this in the trial could have contributed additively with IAA to increase the number of flowers per plant.

\section{Acknowledgments}

The authors thank CEO-ECORFAN, Mexico. S. C. for the support received for the realization of this publication.

\section{Conclusions}

Bacillus subtilis P12, a bacterium that promotes vegetable growth, also has activity on carnation plants cv, Lilliput, increasing the number of flowers per plant.

The inoculation of carnation plants with Bacillus subtilis P12, maintains a constant flowering after 66 dat.

The biochemical properties of indoleacetic acid production and phosphate solubilization exhibited by Bacillus subtilis P12 may have contributed to improving carnation flowering.

\section{References}

Arriaga, R., González, H. M. A., Castillo, G. A. M., Olalde, P. V., Reyes, R. B. G. \& Aguilera, G. L. (2009). Respuesta de Lilium sp. Al fósforo y su relación con Glomus fasciculatum y Bacillus subtilis. Revista Internacional de Botánica Experimental, 78: 91-100. 
Baracaldo, A. A. P., Ibagué, O. A., Flórez, R. V. J. \& Chaves, C. B. (2010). Crecimiento en clavel estándar cv. Nelson en suelo y en sustratos. Bragantia, Campinas, 69(1):1-8.

Chávez, A. L. A., Hernández, M. A., Cabrera, L. A., Luna, M. L. \& Pacheco, A. J. R. (2016). Aislados de Bacillus provenientes de la rizósfera de cactus incrementa la germinación y la floración de Mammillaria spp. (Cactaceae). Revista Argentina de Microbiología, 48(4):333341.

Devi, S. (1999). Effect of nitrogen and phosphorus on growth and flowering of carnation (Dianthus caryophyllus Linn) cv. Caberet. Theses. College of Agriculture Chaudhary Charan Singh Haryana Agricultural University Hisar. 138 p.

Gayosso, R. S., Borges, G. L., Villanueva, C. E., Estrada, B. M. A. \& Garruña, H. R. (2016). Sustrato para producción de flores. Agrociencia 50: 617-631.

Kumar, V., Kumar, V., Umrao, V. \& Singh, M. (2012). Effect of $\mathrm{GA}_{3}$ and IAA on growth and flowering of Carnation. HortFlora Research Spectrum, 1(1): 69-72.

Luna, M. L., Martínez, P. R. A., Hernández, I. M., Arvizu, M. S. F. \& Pacheco, A. J. R. (2013). Caracterización de rizobacterias aisladas de tomate y su efecto en el crecimiento de tomate y pimiento. Revista Fitotecnia Mexicana, 36(1):63-69.

Parmar, T., Baweja, H. S., Dilta, B. S. \& Baweja, P. K. (2020). Impact of environmental factors and mulching on growth, quality and yield of Carnation (Diantus caryophyllus L.) cv. 'Loris'. International Journal of Chemicla Studies 8(5): 1879-1882.

Vessey, J. K. (2003). Plant growth promoting rhizobacteria as biofertilizers. Plant Soil 255:571-586.

Yasmeen, S., Younis, A., Rayit, A., Riaz, A. \& Shabeer, S. (2012). Effect of different substrates on growth and flowering of Dianthus caryophillus cv. 'Chauband mixed'. AmericanEurasian J. Agric. \& Environ. Sci. 12(2):249258.
Zheng, L., Zibin,X. and Song, W. (2020). Effects of substrate and exogenous auxin on the adventitious rooting of the Dianthus caryophyllus L. HortScience, 55(2):170-173. 